AKRUAL 3 (2) (2012): 196-208 e-ISSN: 2502-6380

AKRUAL

Jurnal Akuntansi

http://fe.unesa.ac.id/ojs/index.php/akrl

\title{
PENGARUH CORPORATE SOCIAL RESPONSIBILITY TERHADAP PROFITABILITAS PT. TELKOM TBK SEBAGAI PEMENANG CSR AWARD 2008
}

\author{
Novita Ekasari \\ Alumni Fakultas Ekonomi Universitas Negeri Jember \\ Yenny Christine \\ Alumni Fakultas Ekonomi Universitas Widya Kartika Surabaya \\ Email: nesya_78@yahoo.co.id
}

\begin{abstract}
Abstraksi
Penelitian ini bertujuan untuk menguji pengaruh CSR terhadap profitabilitas PT.TELKOM Tbk yang memperoleh penganugerahan CSR Award 2008. Penelitian ini menggunakan CSR Disclosure Indeks (CSRI) dengan indikator GRI (Global Reporting Initiative) sebagai variabel independen serta tiga variabel dependen profitabilitas perusahaan yang terdiri dari ROA, ROE, dan EPS. Hasil penelitian ini membuktikan penerapan CSR tidak berpengaruh signifikan terhadap ROA dan EPS, namun penerapan CSR berpengaruh secara signifikan terhadap ROE. Hal ini dapat dikarenakan krisis ekonomi global yang terjadi pada tahun 2008 sehingga hasil penelitian ini kurang efektif dan mayoritas investor berorientasi pada kinerja jangka pendek jadi belum mulai menjadikan informasi CSR perusahaan sebagai salah satu tolok ukur dalam investasi.
\end{abstract}

Kata kunci: Corporate Social Responsibility, Profitabilitas, Pemenang CSR Award 2008

\section{PENDAHULUAN}

Selama ini, perusahaan dianggap sebagai lembaga yang dapat memberikan banyak keuntungan bagi masyarakat. Namun dibalik itu semua, keberadaan perusahaan ternyata juga banyak menimbulkan berbagai persoalan sosial dan lingkungan. Karena itu, banyak diskusi mengenai lingkungan dan tanggung jawab untuk membawa perusahaan lebih peduli mengenai lingkungan. Demikian Corporate Social Responsibility (CSR), menjadi wacana yang sedang mengemuka di dunia perusahaan multinasional.

Social responsibility memiliki pesan sosial dan perhatian terhadap lingkungan dan pembangunan di masa datang. Aktivitas sosial perusahaan memiliki kemanfaatan untuk meningkatkan legitimasi stakeholder terhadap perusahaan, termasuk market force dan konsumen jangka panjang. Namun keikutsertaan perusahaan dalam tanggung jawab sosial akan menambah biaya. Menurut hasil penelitian Goukasian dan Whitney (2007:1-30) bahwa perusahaan yang mengeluarkan biaya untuk bertanggungjawab secara sosial dan etis tidak menyebabkan trade-off (pertukarannya) 
negatif dan tetap dapat menampilkan kinerja sebaik perusahaan lain yang tidak mengimplementasikan CSR. Hadi (2011:65) menunjukkan bahwa biaya sosial yang dikeluarkan perusahaan memiliki manfaat meningkatkan kinerja sosial, yaitu meningkatkan legitimasi dan mengurangi komplain stakeholder. Di samping itu, biaya sosial juga dapat meningkatkan image, baik di pasar komoditas maupun pasar modal. Semakin banyaknya bentuk pertanggungjawaban yang dilakukan perusahaan terhadap lingkungannya, maka image perusahaan menurut pandangan masyarakat menjadi meningkat atau citra perusahaan menjadi baik. Investor lebih berminat pada perusahaan yang memiliki citra yang baik di masyarakat karena semakin baiknya citra perusahaan, maka loyalitas konsumen semakin tinggi. Seiring meningkatnya loyalitas konsumen dalam waktu lama maka penjualan perusahaan akan membaik dan pada akhirnya diharapkan tingkat profitabilitas perusahaan juga meningkat (Satyo, 2005:8).

Namun demikian, keseriusan perusahaan melakukan tanggungjawab sosial tersebut tidak terjadi pada keseluruhan perusahaan. Pelaksanaan CSR pun beragam jika dilihat dari segi dimensinya. Hal itu dapat memicu keterbatasan dan kekurangefektifan tanggungjawab sosial. Oleh karenanya dalam penelitian ini penulis meneliti PT.. Telekomunikasi Indonesia Tbk (TELKOM) dimana merupakan perusahaan yang memperoleh penganugerahan CSR Award 2008.

CSR Award diselenggarakan oleh Corporate Forum for Community Development (CFCD), dimana CSR Award diberikan pada perusahaan dengan mengacu pada pembagian kategori : sosial, ekonomi, lingkungan, dan kombinasi dua bidang dan kombinasi tiga bidang. penelitian ini difokuskan kepada PT. Telekomunikasi Indonesia Tbk (TELKOM) karena perusahaan tersebut merupakan satu-satunya pemenang kombinasi ketiga kategori sekaligus. Selain itu TELKOM juga menyediakan laporan keberlanjutan (sustainability report) yang lengkap berdasarkan standar internasional. Hal tersebut akan mengurangi keterbatasan dan kekurangefektifan dalam penilaian tingkat pengungkapan CSR perusahaan.

Dari penjelasan tersebut, maka dapat dirumuskan masalah sebagai berikut:" Apakah penerapan Corporate Social Responsibility berpengaruh terhadap profitabilitas PT. TELKOM Tbk yang memperoleh penganugerahan CSR Award 2008?"

Tujuan penelitian adalah untuk memperoleh bukti empiris pengaruh CSR terhadap profitabilitas PT. TELKOM Tbk yang memperoleh penganugerahan CSR Award 2008.

\section{KAJIAN PUSTAKA \\ Teori Stakeholder}

Teori stakeholder mempertegas bahwa keberadaan perusahaan di tengah lingkungan tidak dapat dilepaskan dengan stakeholder. Mereka adalah para pihak yang memiliki kepentingan langsung maupun tidak langsung terhadap perusahaan. Stakeholder memiliki kemampuan untuk mempengaruhi pemakaian sumber-sumber ekonomi yang digunakan perusahaan. Oleh karena itu power stakeholder ditentukan 
oleh besar kecilnya power yang dimiliki stakeholder atas sumber tersebut (Ghozali dan Chariri, 2007 dalam Kusumadilaga, 2010).

Perusahaan didirikan dan bertahan karena adanya kebutuhan dan permintaan masyarakat. Itulah sebabnya perusahaan tidak akan dapat berfungsi dengan baik dalam pengasingan dari masyarakat tempat di mana perusahaan tersebut beroperasi. Karena itu, pencapaian keuntungan dan kontribusi sosial perusahaan merupakan satu kesatuan (Lindrawati dkk, 2008).

Steiner (2004) yang dikutip oleh Hadi (2011:113) menyatakan bahwa perusahaan perlu membangun nilai lewat kedekatan (intimacy) terhadap stakeholder. Upaya membangun intimacy tersebut dapat dilakukan dengan berbagai aktivitas strategi legitimasi, seperti: memegang etika bisnis, memegang integritas, keterbukaan (responsible care), kepatuhan terhadap aturan, serta citizenship. Strategi berbasis stakeholder berarti membangun nilai perusahaan dengan tetap memperhatikan dan memperhitungkan kepentingan stakeholder dalam kerangka pencapaian tujuan perusahaan (Belkaoui dan Karpik, 1989 dalam Hadi, 2011:113). Jika hal itu disepakati, strategi berbasis stakeholder berarti mendukung tanggung jawab sosial perusahaan (social responsibility) sebagai satu pilar untuk menjamin going concern perusahaan.

\section{CSR (Corporate Social Responsibility)}

Sebuah organisasi dunia World Business Council for Sustainable Development (WBCSD) mendefinisikan CSR sebagai komitmen bisnis untuk memberikan kontribusi bagi pembangunan ekonomi berkelanjutan, melalui kerja sama dengan para karyawan serta perwakilan mereka, keluarga mereka, komunitas setempat maupun masyarakat umum untuk meningkatkan kualitas kehidupan dengan cara yang bermanfaat baik bagi bisnis sendiri maupun untuk pembangunan.

Perkembangan teknologi dan industri yang pesat dituntut untuk memberikan kontribusi positif terhadap lingkungan sekitar. Kontribusi dari perusahaan ini bisa berupa banyak hal, misalnya: bantuan dana, bantuan tenaga ahli dari perusahaan, bantuan berupa barang, dan bantuan-bantuan lainnya. Hal ini menunjukkan bahwa CSR merupakan keseluruhan hubungan antara perusahaan dengan semua stakeholder-nya. Stakeholder di sini termasuk konsumen, karyawan, komunitas, pemilik atau investor, pemerintah, pemasok dan pesaing [Basya (2004) dalam Lindrawati dkk (2007)].

Program-program CSR dikelompokkan menjadi tiga aspek penting, yaitu ekonomi, lingkungan, dan sosial. Kemudian pertanggungjawaban sosial perusahaan diungkapkan di dalam laporan yang disebut Sustainability Reporting. Sebagian dari studi-studi yang dilakukan oleh para peneliti yang mengemukakan pendapat ini menemukan bukti bahwa informasi sosial dibutuhkan oleh para pemakai laporan keuangan. Saat ini pelaporan sosial perusahaan berdasarkan standar GRI (Global Reporting Initiative) banyak diterapkan oleh perusahaan-perusahaan. 


\section{Profitabilitas}

Profitabilitas adalah suatu angka yang menunjukkan kemampuan suatu entitas usaha untuk menghasilkan laba. Menurut Gray et.al, (1995) dalam Nistantya (2010) profitabilitas merupakan faktor yang membuat manajemen menjadi bebas dan fleksibel untuk mengungkapkan pertanggungjawaban sosial kepada pemegang saham. Untuk menghitung tingkat profitabilitas perusahaan dalam penelitian ini menggunakan tiga rasio keuangan sebagai tolak ukur yaitu, ROA, ROE, dan EPS.

\section{Hubungan Penerapan CSR Terhadap Profitabilitas Perusahaan}

Perusahaan didirikan bukan hanya untuk waktu yang sesaat melainkan untuk going concern. Untuk mencapai tujuan tersebut maka perusahaan perlu melaksanakan program Corporate Social Responsibility yang mencakup pemberdayaan people, profit, dan planet. Dengan adanya perhatian dan bantuan yang diberikan oleh korporat terhadap masyarakat baik berupa bantuan dana maupun pelatihan (kemitraan), dan bina lingkungan akan menimbulkan respon positif dari masyarakat. Hal ini pun akan membuat daya beli masyarakat membaik, dan akan menumbuhkan kepedulian masyarakat terhadap produk yang dihasilkan korporat tersebut. Maka secara tidak langsung masyarakat memegang peranan penting dalam upaya peningkatan profitabilitas perusahaan. Menurut Lindrawati dkk, (2008) bahwa pada awal mengimplementasikan CSR akan meningkatkan biaya (cost) bagi perusahaan, namun keuntungan yang akan didapat perusahaan nantinya jauh lebih besar dibandingkan biaya yang dikeluarkan perusahaan.

Kotler (2005) dalam Lenny (2006: 24) memaparkan manfaat melakukan tanggung jawab sosial perusahaan dalam strategi dan operasi bisnis, yaitu: "Meningkatkan penjualan dan saham di pasaran (increased sales and market share), menguatkan posisi merk (strengthened brand positioning), meningkatkan citra dan pengaruh perusahaan (enhanced corporate image and clout), meningkatkan kemampuan untuk menarik, memotivasi dan mempertahankan karyawan (increased ability to attract, motivate, and retain employees), mengurangi biaya operasi (decreased operating cost), meningkatkan kemampuan untuk menarik investor dan analis keuangan (increased appeal to investor and financial analysts)".

Selain itu masih terdapat beberapa keuntungan lain dengan melakukan CSR menurut Kartini (2009:83-93) yaitu: menurunkan biaya operasional perusahaan, meningkatkan volume penjualan dan pangsa pasar, menarik calon investor, pertumbuhan nilai saham yang signifikan, membuat kesejahteraan karyawan lebih baik, mencegah risiko dari dampak sosial, mencegah risiko dari dampak alam. Oleh karena itu program CSR diharapkan dapat menghasilkan hubungan positif yang searah dengan tingkat profitabilitas perusahaan.

\section{Pengembangan hipotesis}

Berdasarkan latar belakang masalah, rumusan masalah dan landasan teori yang telah dikemukakan di atas, maka hipotesis yang diajukan dalam penelitian ini adalah: $\mathrm{Ha}_{1}$ : Penerapan CSR berpengaruh signifikan terhadap ROA perusahaan. 
$\mathrm{Ha}_{2}$ : Penerapan CSR berpengaruh signifikan terhadap ROE perusahaan.

$\mathrm{Ha}_{3}$ : Penerapan CSR berpengaruh signifikan terhadap EPS perusahaan.

\section{METODE PENELITIAN}

Perusahaan yang diteliti adalah PT. TELKOM Tbk dimana sebagai pemenang kombinasi tiga kategori CSR Award tahun 2008. Penelitian ini menggunakan periode uji selama 3 tahun yaitu tahun 2006, 2007, dan 2008. PT. TELKOM Tbk memiliki laporan keuangan maupun laporan keberlanjutan yang lengkap selama tiga tahun tersebut.

Dalam penelitian ini digunakan pendekatan kuantitatif dengan pengujian hipotesis untuk menguji pengaruh CSR terhadap profitabilitas perusahaan. CSR (X) diukur dengan menggunakan CSRI (CSR Disclosure Indeks) dengan indikator GRI (Global Reporting Initiative). Dimana indikator GRI terdiri dari 3 (tiga) fokus pengungkapan yaitu ekonomi, lingkungan, dan sosial. Sementara Profitabilitas digunakan ROA (Y1), ROE (Y2) dan EPS (Y3). ROA menggambarkan kemampuan perusahaan untuk menghasilkan keuntungan dari setiap satu rupiah aset yang digunakan. ROE mengukur kemampuan perusahaan dalam menghasilkan laba berdasarkan modal saham yang dimiliki perusahaan. EPS menunjukkan berapa besar keuntungan (return) yang diperoleh investor atau pemegang saham per lembar saham.

Prosedur pengumpulan data dalam penelitian ini dengan langkah-langkah sebagai berikut: pertama, menelusuri laporan tahunan dan laporan keberlanjutan (Sustainability Reporting) perusahaan sampel dengan instrumen penelitian berupa check list atau daftar pertanyaan-pertanyaan yang berisi item-item pengungkapan pertanggungjawaban sosial. Kedua, menghitung variabel profitabilitas (ROA, ROE, EPS) dari perusahaan sampel pada periode penelitian yang diambil (tahun 2006, 2007, 2008). Ketiga hasil perhitungan nilai CSRI dan rasio profitbilitas (ROA, ROE, EPS) yang digunakan sebagai input data diolah oleh alat analisis SPSS 13.

Analisis data menggunakan uji regresi curve analisis untuk menguji hubungan linieritas. Hal ini dikarenakan penelitian ini memiliki lebih dari satu dependen (Y) dan setiap hubungan antar dua variabel memiliki banyak pola (model) hubungan. Untuk melihat hubungan antar variabel yang diuji mengikuti model yang mana dapat melalui menu CURVE ESTIMATION pada SPSS 13. Kemudian menggunakan regresi linier sederhana untuk menguji pengaruh CSR terhadap profitabilitas perusahaan serta menggunakan Uji t untuk menguji apakah pertanyaan hipotesis benar. Dengan $(\alpha)=$ $5 \%$ dan nilai t tabel. 
HASIL DAN PEMBAHASAN

Hasil Analisis CSR terhadap Profitabilitas Menggunakan Uji Regresi Curve Analisis

Tabel 1. Hasil Roa Menggunakan Uji Regresi Curve Analisis

Dependent Variable: ROA

\begin{tabular}{llllllllll}
\hline Equation & \multicolumn{1}{l}{ Model Summary } & & \multicolumn{7}{c}{ Parameter Estimates } \\
\hline \multirow{2}{*}{ Linear } & R Square & $\mathbf{F}$ & $\mathbf{d f 1}$ & $\mathbf{d f 2}$ & Sig. & Constant & $\mathbf{b 1}$ & $\mathbf{b 2}$ & $\mathbf{b 3}$ \\
Logarithmic & .818 & 4.510 & 1 & 1 & .280 & .190 & -.179 & & \\
Inverse & .768 & 3.302 & 1 & 1 & .320 & .072 & -.052 & \\
Quadratic & 1.000 & .000 & 2 & 0 &. & -.043 & 1.475 & -2.671 & \\
Cubic & 1.000 &. & 2 & 0 &. & .084 & .000 & 2.805 & -6.449 \\
Compound & .841 & 5.297 & 1 & 1 & .261 & .203 & .259 & & \\
Power & .793 & 3.821 & 1 & 1 & .301 & .083 & -.391 & & \\
S & .730 & 2.704 & 1 & 1 & .348 & -2.390 & .107 & & \\
Growth & .841 & 5.297 & 1 & 1 & .261 & -1.595 & -1.350 & & \\
Exponential & .841 & 5.297 & 1 & 1 & .261 & .203 & -1.350 & & \\
Logistic & .841 & 5.297 & 1 & 1 & .261 & 4.926 & 3.857 & & \\
\hline
\end{tabular}

The independent variable is CSRI.

Tabel 2. Hasil Roe Menggunakan Uji Regresi Curve Analisis

Dependent Variable: ROE

\begin{tabular}{llllllllll}
\hline \multicolumn{1}{c}{ Equation } & \multicolumn{4}{c}{ Model Summary } & \multicolumn{5}{c}{ Parameter Estimates } \\
\hline & R Square & F & df1 & df2 & Sig. & Constant & b1 & b2 & b3 \\
Linear & .997 & 322.555 & 1 & 1 & .035 & .479 & -.419 & & \\
Logarithmic & .986 & 70.436 & 1 & 1 & .075 & .198 & -.124 & & \\
Inverse & .964 & 26.438 & 1 & 1 & .122 & .225 & .035 & & \\
Quadratic & 1.000 & .000 & 2 & 0 &. & .415 & .039 & -.740 & \\
Cubic & 1.000 & .000 & 2 & 0 &. & .415 & .039 & -.740 & .000 \\
Compound & .995 & 214.472 & 1 & 1 & .043 & .505 & .299 & & \\
\hline
\end{tabular}




\begin{tabular}{llllllll}
\hline Power & .983 & 57.475 & 1 & 1 & .083 & .225 & -.358 \\
$\mathrm{~S}$ & .959 & 23.215 & 1 & 1 & .130 & -1.415 & .101 \\
Growth & .995 & 214.472 & 1 & 1 & .043 & -.684 & -1.208 \\
Exponential & .995 & 214.472 & 1 & 1 & .043 & .505 & -1.208 \\
Logistic & .995 & 214.472 & 1 & 1 & .043 & 1.981 & 3.345 \\
\hline
\end{tabular}

The independent variable is CSRI.

Tabel 3. Hasil EPS Menggunakan Uji Regresi Curve Analisis

Dependent Variable: EPS

\begin{tabular}{|c|c|c|c|c|c|c|c|c|c|}
\hline \multirow[t]{2}{*}{ Equation } & \multicolumn{5}{|c|}{ Model Summary } & \multicolumn{4}{|c|}{ Parameter Estimates } \\
\hline & $\begin{array}{c}\mathbf{R} \\
\text { Square }\end{array}$ & $\mathbf{F}$ & df1 & df2 & Sig. & Constant & b1 & b2 & b3 \\
\hline Linear & .171 & .206 & 1 & 1 & .729 & 640.419 & -226.497 & & \\
\hline Logarithmic & .126 & .144 & 1 & 1 & .769 & 500.381 & -58.096 & & \\
\hline Inverse & .081 & .089 & 1 & 1 & .816 & 524.859 & 13.373 & & \\
\hline Quadratic & 1.000 & .000 & 2 & 0 & . & -745.500 & 9582.837 & -15837.946 & \\
\hline Cubic & 1.000 & . & 2 & 0 & . & 84.569 & .000 & 19729.608 & -41893.468 \\
\hline Compound & .176 & .214 & 1 & 1 & .724 & 641.255 & .678 & & \\
\hline Power & .131 & .150 & 1 & 1 & .764 & 503.927 & -.100 & & \\
\hline S & .085 & .093 & 1 & 1 & .811 & 6.264 & .023 & & \\
\hline Growth & .176 & .214 & 1 & 1 & .724 & 6.463 & -.389 & & \\
\hline Exponential & .176 & .214 & 1 & 1 & .724 & 641.255 & -.389 & & \\
\hline Logistic & .176 & .214 & 1 & 1 & .724 & .002 & 1.476 & & \\
\hline
\end{tabular}

The independent variable is CSRI.

Dari hasil output yaitu tiga tabel di atas menunjukkan bahwa model linier lebih tepat diterapkan kepada model hubungan antar variabel yang dianalisis dibanding dengan model kubik dan kuadratik. Meskipun nilai R2 pada model kubik dan kuadratik paling besar, namun jika dilihat dari signifikannya $(\mathrm{p}<0.05)$ tidak terdapat nilai signifikansi pada model kubik dan kuadratik maka dapat disimpulkan lebih tepat menggunakan model linier dibanding model lain. 


\section{Hasil ROA Menggunakan Uji Regresi Linier Sederhana}

Tabel 4. Koefisien Determinasi

\begin{tabular}{|l|r|r|r|r|r|}
\hline \multicolumn{7}{|c|}{ Model Summary } \\
\hline Model & \multicolumn{1}{|c|}{$\mathrm{R}$} & R Square & $\begin{array}{c}\text { Adjusted } \\
\text { R Square }\end{array}$ & $\begin{array}{c}\text { Std. Error of } \\
\text { the Estimate }\end{array}$ & $\begin{array}{c}\text { Durbin- } \\
\text { Watson }\end{array}$ \\
\hline 1 & $.905^{\mathrm{a}}$ & .818 & .637 & .012786 & 2.770 \\
\hline
\end{tabular}

a. Predictors: (Cons tant), CSRI

b. Dependent Variable: ROA

Besarnya angka $\mathrm{R}$ square adalah 0,818 . Angka tersebut menunjukkan bahwa besar pengaruh CSR terhadap ROA adalah 81,8\%. Adapun sisanya sebesar 18,2\% dipengaruhi oleh faktor lain.

Tabel 5. Hasil Uji t

Coefficients ${ }^{\mathrm{a}}$

\begin{tabular}{|c|c|c|c|c|c|c|}
\hline \multirow{2}{*}{\multicolumn{2}{|c|}{ Model }} & \multicolumn{2}{|c|}{$\begin{array}{l}\text { Unstandardized } \\
\text { Coefficients }\end{array}$} & \multirow{2}{*}{$\begin{array}{c}\begin{array}{c}\text { Standardized } \\
\text { Coefficients }\end{array} \\
\text { Beta } \\
\end{array}$} & \multirow[b]{2}{*}{$\mathrm{t}$} & \multirow[b]{2}{*}{ Sig. } \\
\hline & & B & Std. Error & & & \\
\hline & (Constant) & .190 & .025 & & 7.626 & .083 \\
\hline & CSRI & -.179 & .084 & -.905 & -2.124 & .280 \\
\hline
\end{tabular}

a. Dependent Variable: ROA

Pada tabel 5 variabel interaksi antara CSRI dan ROA memiliki nilai t hitung 2,124 dengan tingkat signifikansi 0,280 (tidak signifikan, karena -t hitung > -t tabel dan $\mathrm{p}>0,05$ ), menunjukkan bahwa penerapan CSR tidak berpengaruh signifikan terhadap ROA (Ha1 ditolak). Hasil penelitian ini mendukung penelitian yang dilakukan Mandala (2010) juga menunjukkan CSR tidak berpengaruh terhadap ROA.

\section{Hasil ROE Menggunakan Uji Regresi Linier Sederhana}

Tabel 6. Koefisien Determinasi

\begin{tabular}{|l|r|r|r|r|r|}
\multicolumn{7}{|c|}{ Model Summary } \\
\hline Model & R & R Square & $\begin{array}{l}\text { Adjusted } \\
\text { R Square }\end{array}$ & $\begin{array}{c}\text { Std. Error of } \\
\text { the Estimate }\end{array}$ & $\begin{array}{c}\text { Durbin- } \\
\text { Watson }\end{array}$ \\
\hline 1 & $.998^{\mathrm{a}}$ & .997 & .994 & .003544 & 2.770 \\
\hline
\end{tabular}

a. Predictors: (Constant), CSRI

b. Dependent Variable: ROE

Besarnya angka $\mathrm{R}$ square adalah 0,997 . Angka tersebut menunjukkan bahwa besar pengaruh CSR terhadap ROE adalah 99,7\%. Adapun sisanya sebesar 0,3\% dipengaruhi oleh faktor lain. 


\section{Tabel 7. Hasil Uji t}

Coefficients $^{\mathrm{a}}$

\begin{tabular}{|cc|r|r|r|r|r|}
\hline \multirow{2}{*}{ Model } & \multicolumn{2}{|c|}{$\begin{array}{c}\text { Unstandardized } \\
\text { Coefficients }\end{array}$} & $\begin{array}{c}\text { Standardized } \\
\text { Coefficients }\end{array}$ & & \\
\cline { 3 - 5 } & & \multicolumn{1}{|c|}{$\mathrm{B}$} & Std. Error & \multicolumn{1}{c|}{ Beta } & \multicolumn{1}{c|}{$\mathrm{t}$} & \multicolumn{1}{c|}{ Sig. } \\
\hline 1 & (Constant) & .479 & .007 & & 69.300 & .009 \\
& CSRI & -.419 & .023 & -.998 & -17.960 & .035 \\
\hline
\end{tabular}

a. Dependent Variable: ROE

Pada tabel 7 variabel interaksi antara CSRI dan ROE memiliki nilai t hitung 17,960 dengan tingkat signifikansi 0,035 (signifikan, karena -t hitung < -t tabel dan $\mathrm{p}$ $<0,05)$, menunjukkan bahwa penerapan CSR berpengaruh secara signifikan terhadap ROE (Ha2 diterima). Hasil penelitian ini mendukung penelitian yang dilakukan Dahlia dan Siregar (2008) yang menyatakan bahwa tingkat pengungkapan CSR dalam laporan tahunan perusahaan berpengaruh positif terhadap variabel ROE.

\section{Hasil EPS Menggunakan Uji Regresi Linier Sederhana}

\section{Tabel 8. Koefisien Determinasi}

\begin{tabular}{|l|r|r|r|r|r|}
\hline \multicolumn{7}{|c|}{ Model Summar $\mathbf{y}^{\mathrm{s}}$} \\
\hline Model & $\mathrm{R}$ & $\mathrm{R}$ Square & $\begin{array}{c}\text { Adjusted } \\
\text { R Square }\end{array}$ & $\begin{array}{c}\text { Std. Error of } \\
\text { the Estimate }\end{array}$ & $\begin{array}{c}\text { Durbin- } \\
\text { Watson }\end{array}$ \\
\hline 1 & $.413^{\mathrm{a}}$ & .171 & -.659 & 75.822905 & 2.770 \\
\hline
\end{tabular}

a. Predictors: (Constant), CSRI

b. Dependent Variable: EPS

Besarnya angka R square adalah 0,171. Angka tersebut menunjukkan bahwa besar pengaruh CSR terhadap EPS adalah 17,1\%. Adapun sisanya sebesar 82,9\% dipengaruhi oleh faktor lain.

Tabel 9. Hasil Uji t

\section{Coefficients}

\begin{tabular}{|cc|r|r|r|r|r|}
\hline \multirow{2}{*}{ Model } & \multicolumn{2}{|c|}{$\begin{array}{c}\text { Unstandardized } \\
\text { Coefficients }\end{array}$} & \multicolumn{2}{c|}{$\begin{array}{c}\text { Standardized } \\
\text { Coefficients }\end{array}$} & & \\
\cline { 3 - 5 } & \multicolumn{1}{|c|}{$\mathrm{B}$} & Std. Error & Beta & $\mathrm{t}$ & \multicolumn{1}{c|}{ Sig. } \\
\hline 1 & (Constant) & 640.419 & 147.966 & & 4.328 & .145 \\
& CSRI & -226.497 & 499.441 & -.413 & -.454 & .729 \\
\hline
\end{tabular}

a. Dependent Variable: EPS

Pada tabel 8 variabel interaksi antara CSRI dan EPS memiliki nilai t hitung 0,454 dengan tingkat signifikansi 0,729 (tidak signifikan, karena -t hitung > -t tabel dan $\mathrm{p}>0,05)$, menunjukkan bahwa penerapan CSR tidak berpengaruh secara signifikan terhadap EPS (Ha3 ditolak). 


\section{SIMPULAN DAN SARAN}

\section{Simpulan}

Penelitian ini bertujuan untuk meneliti pengaruh penerapan Corporate Social Responsibility terhadap profitabilitas PT. TELKOM Tbk yang merupakan pemenang CSR Award tahun 2008. Setelah melakukan pengolahan data, pengujian hipotesis, analisis dan pembahasan yang berkaitan dengan permasalahan, maka dapat dirumuskan kesimpulan sebagai berikut:

1. Pengaruh CSR Terhadap ROA

Rasio ROA memiliki hubungan yang erat dengan CSR, hal ini dapat melihat nilai $\mathrm{R}$ Square yang tinggi yaitu sebesar 0,818 . Berdasarkan hasil uji t didapat bahwa penerapan CSR tidak berpengaruh signifikan terhadap ROA. Hal ini dapat dikarenakan krisis ekonomi global yang terjadi pada tahun 2008 sehingga hasil penelitian ini kurang efektif.

2. Pengaruh CSR terhadap ROE

Rasio ROE memiliki hubungan yang erat dengan CSR, hal ini dapat melihat nilai R Square yang tinggi yaitu sebesar 0,997.Berdasarkan hasil uji t didapat bahwa penerapan CSR berpengaruh signifikan terhadap ROE. Hasil penelitian ini mengindikasikan bahwa perilaku etis perusahaan berupa tanggung jawab sosial terhadap lingkungan sekitarnya memberikan dampak, yang dalam jangka panjang akan tercermin pada keuntungan perusahaan.

3. Pengaruh CSR terhadap EPS

Rasio EPS tidak memiliki hubungan yang erat dengan CSR, hal ini dapat melihat nilai R Square yang rendah yaitu sebesar 0,171 . Berdasarkan hasil uji t didapat bahwa penerapan CSR tidak berpengaruh signifikan terhadap EPS. Hal ini mungkin disebabkan kebanyakan investor berorientasi pada kinerja jangka pendek jadi belum mulai menjadikan informasi CSR perusahaan sebagai salah satu tolak ukurnya dalam investasi.

\section{Saran}

1. Saran untuk peneliti selanjutnya adalah :

a. Penelitian selanjutnya hendaknya mengkaji perusahaan lain, diluar perusahaan jasa. Dapat juga menambah jumlah sampel penelitian dan memperpanjang waktu pengamatan.

b. Penelitian selanjutnya dapat menambah proksi profitabilitas atau mengganti dengan variabel lain.

c. Penelitian selanjutnya dapat dimasukkan variabel-variabel kontrol lainnya yang berpengaruh terhadap profitabilitas.

d. Penelitian selanjutnya dapat menggunakan perusahaan yang terdaftar di bursa efek luar negeri (misalnya bursa NYSE).

2. Saran bagi manajemen :

Terus meningkatkan penerapan CSR dimana hal tersebut dapat menunjukan besarnya perhatian perusahaan bagi para stakeholder dan stockholder dan berdampak pada citra dan keberlanjutan perusahaan. 
3. Saran bagi investor :

Dalam menginvestasikan dananya perlu mempertimbangkan menanamkan modalnya pada perusahaan yang memiliki komitmen CSR dan mengurangi anggapan bahwa penerapan CSR yang berbiaya besar justru mengurangi return yang diharapkan investor. 


\section{DAFTAR PUSTAKA}

CFCD (Corporate Forum for Community Development). CSR Award tahun 2005 dan 2008. Diakses di www.cfcdcenter.or.id, pada 19 Februari 2011.

Dahlia, Lely dan Silvia Veronica Siregar. 2008. "Pengaruh Corporate Social Responsibility Terhadap Kinerja Perusahaan. Studi Empiris Pada Perusahaan Yang Tercatat Di Bursa Efek Indonesia Pada Tahun 2005 dan 2006”. Pontianak:Simposium Nasional Akuntansi XI.

Goukasian, Levon and Keith L. Whitney. 2007. Do Ethically and Socially Responsible Under-Perform? Evidence from Financial and Operating Performances. Business Administration Division, March.

GRI (Global Reporting Initiative). Indikator-Indikator GRI. Diakses di www.globalreporting.org, diakses pada tanggal 25 Februari 2011.

Hadi, Nor. 2011. Corporate Social Responsibility. Yogyakarta:Graha Ilmu.

Kartini, Dwi. 2009. Corporate Social Responsibility : Transformasi Konsep Sustainability Management dan Implementasi di Indonesia. Bandung: PT. Refika Aditama.

Kusumadilaga, Rimba. 2010. Pengaruh Corporate Social Responsibility Terhadap Nilai Perusahaan dengan Profitabilitas sebagai Variabel Moderating. Semarang:Universitas Diponegoro.

Lenny, F. 2006. Strategi Komunikasi Corporate Social Responsibility PT. TELKOM DIVRE V. Surabaya:Universitas Kristen Petra.

Lindrawati. Nita, Felicia. dan J.Th, Budianto T. 2008. "Pengaruh Corporate Social Responsibility Terhadap Kinerja Keuangan Perusahaan yang Terdaftar Sebagai 100 Best Corporate Citizens oleh KLD Research and Analytics." Majalah Ekonomi. Tahun XVIII, No. 1 April:66-83.

Mandala, James Fransiade Rizalius. 2010. "Pengaruh Penganugerahan CSR Award 2005 Terhadap Profitabilitas Perusahaan”. Surabaya:Universitas Widya Kartika.

Nistantya, Dewa Sancahya. 2010. Pengaruh Corporate Social Responsibility terhadap Profitabilitas Perusahaan (Studi Kasus pada Perusahaan Perbankan yang Listing di BEI tahun 2007 Sampai dengan Tahun 2009). Surakarta:Universitas Sebelas Maret.

PT. Telekomunikasi Indonesia, Tbk. Laporan Keberlanjutan/Sustainability Report tahun 2006-2008. Diakses di www.telkom.co.id, pada tanggal 22 Maret 2011.

Sarwono, Jonathan. 2006. Analisis Data Penelitian Menggunakan SPSS 13. Yogyakarta:Andi.

Satyo, Nur Kurniawan. 2005. "Sustainability Reporting: Paradigma Baru Pelaporan Perusahaan”. Media Akuntansi. Edisi 47, Tahun XII, Juli. Hal. 7-9. 
WBCSD (World Business Counsil for Sustainable Development). 2002. Making Good Business Sense. Diakses di www.wbcsd.org, the Switzerland pada tanggal 17 Februari 2011.

Widhiarso, Wahyu. 2010. Uji Linieritas Hubungan. Manuskrip tidak dipublikasikan. Yogyakarta:Fakultas Psikologi UGM. 